\title{
SLC25A5 Gene
}

National Cancer Institute

\section{Source}

National Cancer Institute. SLC25A5 Gene. NCI Thesaurus. Code C37300.

This gene plays a regulatory role in the production and utilization of ATP. 